\title{
Genetic Analysis of Carasobarbus Karaman, 1971 (Actinopterygii Cyprinidae) in Anatolia $^{[*]}$
}

\author{
Didem BAHADIR ${ }^{1}$ İsmail AKSU ${ }^{2} \quad$ Yusuf BEKTAŞ $^{3^{*}}$ \\ ${ }^{I}$ Istanbul Directorate of Provincial Agriculture and Forestry, İstanbul, Turkey. \\ ${ }^{2}$ Recep Tayyip Erdogan University, Faculty of Fisheries and Aquatic Sciences, Rize, Turkey. \\ ${ }^{3 *}$ Recep Tayyip Erdogan University, Faculty of Arts and Sciences, Biology, Rize, Turkey.
}

Atıf yapmak için: Bahadir, D., Aksu, I. \& Bektas, Y. (2020). Anadolu'daki Carasobarbus Karaman, 1971 (Actinopterygii Cyprinidae) Genusunun Genetik Analizi, Anadolu Çev. ve Hay. Dergisi, 520-526.

How to cite: Bahadir, D., Aksu, I. \& Bektas, Y. (2020). Genetic Analysis of Carasobarbus Karaman, 1971 (Actinopterygii Cyprinidae) in Anatolia. J. Anatolian Env. and Anim. Sciences, 520-526.

*Sorumlu yazarın:

Yusuf BEKTAȘ

Recep Tayyip Erdogan University, Faculty of

Arts and Sciences, Biology, Rize, Turkey.

$\triangle$ : yusuf.bektas.tr@gmail.com

Cep telefonu : +90(505) 4560423

Telefon : $+90(464) 2234093 / 1833$

Faks $\quad:+90(464) 2234019$
Abstract: We sequenced the complete mitochondrial cytochrome b gene (1141 bp) of 70 individuals from ten populations of three Carasobarbus species in Anatolia. Totally eight haplotypes were identified. The intraspecies genetic distance ranged from $0.00 \%$ to $0.21 \%$, while it varied from $2.6 \%$ to $9.0 \%$ for interspecies. Except for Gaziantep samples with low sample size, high haplotype diversity $(\mathrm{Hd}=0.590-0.833)$ and low nucleotide diversity $(\mathrm{Pi}=0.05-0.65)$ values can be explained by the presence of small populations sensitive to genetic drift and founder effects. Phylogenetic analyses constructed with neihgbour joining, maximum likelihood and maximum parsimony generated similar topologies supported by high bootstrap values. Phylogenetic tree topologies showed that the C. apoensis haplotype was located in the $C$. luteus species. Therefore, the validity of species status of $C$. apoensis should be checked morphologically. On the other hand, since the Kahta population in C. luteus has a remarkably high genetic diversity, it must be re-evaluated morphologically. The tectonic uplift of the Anatolian Plateau between the African and European plates during the Pliocene period may have probably prevented the presence of Carasobarbus in the west of the Anatolian diagonal.

Keywords: Anatolia, Carasobarbus, mtDNA, Phylogeny.

\section{Anadolu'daki Carasobarbus Karaman, 1971 (Actinopterygii Cyprinidae) Genusunun Genetik Analizi}

*Corresponding author's: Yusuf BEKTAȘ

Recep Tayyip Erdoğan Üniversitesi, Fen Edebiyat Fakültesi, Biyoloji Bölümü, Rize, Türkiye.

冈: yusuf.bektas.tr@gmail.com

Mobile telephone: +90 (505) 4560423

Telephone : $+90(464) 2234093 / 1833$

Fax $\quad:+90(464) 2234019$
Öz: Anadolu'daki üç Carasobarbus türünün 10 populasyonundan 70 bireyin mitokondri sitokrom b geninin (1141 bp) DNA dizin analizi yapılmıştır. Toplamda sekiz haplotip tanımlandı. Sitokrom b veri analizi kullanılarak, tür içi genetik mesafenin $\% 0,00$ ile $\% 0,21$ arasında, türler arası için ise $\% 2,6$ ile $\% 9,0$ arasında değiștiği belirlenmiștir. Yeterli örneklem büyüklüğüne sahip olmayan Gaziantep örnekleri hariç yüksek haplotip çeşitlilik $(\mathrm{Hd}=0,590-0,833)$ ve düşük nükleotit çeşitlilik $(\mathrm{Pi}=0,05-0,65)$ değerleri, genetik sürüklenme ve kurucu etkilere karşı duyarlı olan küçük populasyonların varlığı ile açıklanabilir. Komşu birleştirme, maksimum tutumluluk ve maksimum olasılık metotları yoluyla oluşturulan filogenetik analizler yüksek güvenirlilik değerleri ile desteklenen benzer topolojiler üretmiştir. Filogenetik ağaç topolojileri gösterdi ki $C$. apoensis haplotipleri $C$. luteus haplotipleri içinde konumlandığı için türün geçerliliği morfolojik olarak kontrol edilmelidir. Diğer taraftan, C. luteus içindeki Kahta populasyonu dikkate değer düzeyde yüksek genetik çeşitliğe sahip olduğundan morfolojik olarak mutlaka yeniden değerlendirilmelidir. Pliyosen döneminde Afrika ve Avrupa levhaları arasındaki çarpışmadan kaynaklanan Anadolu Platosu'nun tektonik yükselişi muhtemelen Anadolu köşegeninin batısında Carasobarbus'un varlı̆̆ını engellemiştir.

Anahtar kelimeler: Anadolu, Carasobarbus, Filogeni, mtDNA. 


\section{INTRODUCTION}

Members of the genus Carasobarbus, defined by Karaman (1971), are distributed in Southwest Asia, Northwest Africa, Mesopotamia and Southwestern Arabian peninsulas and are an important element for ichthyofauna in these regions (Froese \& Pauly, 2016). Carasobarbus genus, which has nine species in the world, is represented with three species (C. luteus, C. kosswigi and C. chantrei) in Turkey (Borkenhagen \& Krupp, 2013). One of these, Carasobarbus luteus (Heckel, 1843) distributed in the Euphrates, Tigris and Kueik river systems (Gökçek et al., 2008; Kuru, 1979; Ünlü, 1991), C. kosswigi inhabit in the Euphrates and Tigris drainages (Abdoli, 2000), and C. chantrei (Sauvage, 1882) distributed in the Orontes river and Dam Tahtalıköprü.

Studying the Carasobarbus species dispersed in Iran and its neighboring regions, Borkenhagen found two different sets of haplotypes for $C$. luteus based on cytochrome b sequences. The first is widespread, consistent with the biogeographic hypothesis that points to a recent isolation between many populations as a result of rising sea levels following the recent Pleistocene glaciation. The range of the latter was limited to the Khabur River in Syria. They discussed the possibility that one of these groups corresponded to C. albus, but suggested that C. luteus was more likely to be a single species representing two different mitochondrial lineages. They concluded that the nucleotide diversity in C. kosswigi and C. sublimus was high, possibly due to the small population size and the resulting genetic shift. Borkenhagen and Krupp, (2013) revised the genus Carasobarbus based on comparative morphological studies of approximately 1300 preserved specimens from the collections of various museums and newly collected materials. In this study, in which $C$. apoensis, C. canis, C. chantrei, C. exulatus, $C$. fritschii, C. harterti, C. kosswigi, C. luteus and C. sublimus formed a monophyletic group, they described the species in detail and formed a diagnosis key as a result of reevaluation of their taxonomic status. Parmaksı and Eskici, (2018) conducted a sequence analysis of the mtDNA COI locus from 4 populations to determine the genetic variation of $C$. luteus populations. They revealed the genetic diversity of the species with 9 polymorphic regions and 4 haplotypes determined for cyt $b$ gene (625 bp) by DNA sequence analysis.

Although a limited number of taxonomic and population genetics studies based on morphological and molecular techniques have been conducted, a phylogeny study involving all Carasobarbus species in Turkey has not yet been conducted. The aim of this study is to reveal the phylogeny and phylogeography of valid Carasobarbus species using mitochondrial cytochrome b gene sequences.

\section{MATERIAL and METHOD}

Sampling: A total 70 Carasobarbus were sampled from ten locations in the main tributary systems in Eastern Anatolia such as Tigris, Euphrates, and Kueik River (Table 1). The sampled fish were classified and labeled according to the species identification key. Approximately $30 \mathrm{mg}$ of fins was removed from each fish, stored in $96 \%$ ethanol until DNA extraction and transferred to the Genetic laboratory, Faculty of Fisheries, Recep Tayyip Erdogan University where genetic studies were performed. Sampling and experimental studies are consistent with the universal ethical standarts. The study was approved by the Ethics Committee of Recep Tayyip Erdogan University (Decision No: 2014/72).

Table 1. Sampling and location information

\begin{tabular}{|c|c|c|}
\hline Species and their locations & Coordinates & $\mathbf{N}$ \\
\hline \multicolumn{3}{|l|}{ Carasobarbus luteus } \\
\hline Kueik River, Kilis & $\begin{array}{l}36^{\circ} 47^{\prime} 49.4 " \mathrm{~K} \\
36^{\circ} 55^{\prime} 02.1^{\prime \prime D}\end{array}$ & 15 \\
\hline $\begin{array}{l}\text { Anbar Stream, Tigris River, Hani, } \\
\text { Diyarbakır }\end{array}$ & $\begin{array}{l}38^{\circ} 18^{\prime} 12.6^{\prime \prime} \mathrm{K} \\
40^{\circ} 26^{\prime} 35.5^{\prime \prime} \mathrm{D}\end{array}$ & 6 \\
\hline $\begin{array}{l}\text { Merziman Stream, Euphrates River, } \\
\text { Yavuzeli, Gaziantep }\end{array}$ & $\begin{array}{l}37^{\circ} 19^{\prime} 40.5^{\prime \prime} \mathrm{K} \\
37^{\circ} 40^{\prime} 04.2^{\prime \prime D}\end{array}$ & 2 \\
\hline $\begin{array}{l}\text { Karasu Stream, Euphrates River, Araban, } \\
\text { Gaziantep }\end{array}$ & $\begin{array}{l}37^{\circ} 24 ' 23.6 " \mathrm{~K} \\
37^{\circ} 41^{\prime} 12.9^{\prime \prime} \mathrm{D}\end{array}$ & 2 \\
\hline $\begin{array}{l}\text { Çamçayı Stream, Euphrates River, } \\
\text { Siverek, Şanlıurfa }\end{array}$ & $\begin{array}{l}37^{\circ} 39^{\prime} 05.5^{\prime \prime} \mathrm{K} \\
39^{\circ} 13^{\prime} 50.8^{\prime \prime D}\end{array}$ & 10 \\
\hline $\begin{array}{l}\text { Kahta Stream, Euphrates River, Kocahisar, } \\
\text { Adiyaman }\end{array}$ & $\begin{array}{l}37^{\circ} 57^{\prime} 48.9^{\prime \prime} \mathrm{K} \\
38^{\circ} 39^{\prime} 44.7^{\prime \prime} \mathrm{D}\end{array}$ & 9 \\
\hline $\begin{array}{l}\text { Çataltepe Stream, Euphrates River, } \\
\text { Ziyaret, Kahta, Adıyaman }\end{array}$ & $\begin{array}{l}37^{\circ} 45^{\prime} 00.3 " \mathrm{~K} \\
38^{\circ} 35^{\prime} 29.7^{\prime \prime D}\end{array}$ & 3 \\
\hline \multicolumn{3}{|l|}{ Carasobarbus chantrei } \\
\hline $\begin{array}{l}\text { Karasu Stream, Tahtaköprü Dam, Orontes } \\
\text { River, Hatay }\end{array}$ & $\begin{array}{l}36^{\circ} 49^{\prime} 40.2^{\prime \prime} \mathrm{K} \\
36^{\circ} 39^{\prime} 47.6^{\prime \prime} \mathrm{D}\end{array}$ & 11 \\
\hline $\begin{array}{l}\text { Muratpaşa Stream, Orontes River, } \\
\text { Kırıkhan, Hatay }\end{array}$ & $\begin{array}{l}36^{\circ} 29^{\prime} 15.6^{\prime \prime} \mathrm{K} \\
36^{\circ} 28^{\prime} 04.1^{\prime \prime} \mathrm{D}\end{array}$ & 6 \\
\hline $\begin{array}{l}\text { Karasu Stream, Orontes River, Kırıkhan, } \\
\text { Hatay }\end{array}$ & $\begin{array}{l}36^{\circ} 27^{\prime} 55.0^{\prime \prime} \mathrm{K} \\
36^{\circ} 22^{\prime} 45.0^{\prime \prime} \mathrm{D}\end{array}$ & 6 \\
\hline \multicolumn{3}{|l|}{ Carasobarbus kosswigi } \\
\hline SMF31325 & KU524935 & 1 \\
\hline Total & & 71 \\
\hline
\end{tabular}

DNA Extraction, Polymerase Chain Reaction and Sequencing: Genomic DNA was extracted from approximately fin tissues using the DNeasy Blood \& Tissue Kit (Qiagen, USA) according to the manufacturer's protocol and stored in absolute ethanol at $-20{ }^{\circ} \mathrm{C}$ for molecular studies. Samples of DNA were resolved in horizontal $0.8 \%$ agarose gels. The gels were submerged in 1x TAE (Tris-Acetate-EDTA) buffer containing $0.5 \mu \mathrm{g} / \mathrm{ml}$ ethidium bromide and visualized under ultraviolet light (Quantum ST4, Transilluminator + Quantum Capt Softwares, Vilber Lourmat, France).

The polymerase chain reaction (PCR) was used to amplify the mtDNA cytochrome $b$ (1141 bp) with the universal cyt $b$ primers: L14724 (5'-GTG ACT TGA AAA ACC ACC GTT G-3') and H15915 (5'-CAA CGA TCT CCG GTT TAC AAG AC-3') published by Anderson et al., 
(1981). The volume of the PCRs was $50 \mu$ and contained $5 \mu \mathrm{l} 10 \times$ reaction buffer, $2 \mu \mathrm{l}$ dNTPs $(10 \mathrm{mM}), 0.2 \mu \mathrm{l}$ of each primer $(10 \mathrm{pmol} / \mu \mathrm{l}), 3 \mu \mathrm{l}$ DNA-extract $(50 \mathrm{ng} / \mathrm{ml}), 0.2$

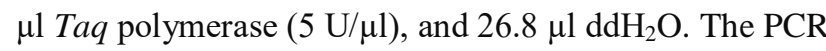
conditions consisted of preheating at $94^{\circ} \mathrm{C}$ for $3 \mathrm{~min}$, followed by 35 cycles of $94^{\circ} \mathrm{C}$ for $30 \mathrm{~s}, 61^{\circ} \mathrm{C}$ for $30 \mathrm{~s}$, and $72^{\circ} \mathrm{C}$ for $60 \mathrm{~s}$, finalised at $72^{\circ} \mathrm{C}$ for $5 \mathrm{~min}$, with a final 5 min extension at $72^{\circ} \mathrm{C}$ on T100TM PCR Gradient Thermal Cycler (Bio-Rad, Hercules, USA). PCR products were displayed under the UV Quantum-Capt ST4 system (Vilber Lourmat, Marne-La-Vallee, France). PCR products were purified with the Qiagen purification kit. Automated bi-directional sequencing was performed using the Big Dye Terminator v3.1 Cycle Sequencing Ready Reaction Kit (Applied Biosystems, USA) and an ABI PRISM 3730x1 Genetic Analyser (Applied Biosystem, USA) sequencer.

Data Analyses: MtDNA cytochrome $b$ sequences were aligned and corrected manually with Bioedit 7.0.0 (Hall, 1999). The number of haplotype, number of polymorphic sites, the nucleotide composition, haplotype and nucleotide diversity were calculated using the software DNASP v.5.10.01 (Librado \& Rozas, 2009). Interspecific and intraspecific pairwise distances were calculated using Kimura two-parameter model (K2P; Kimura, 1980) implemented in MEGA version X (Kumar et al., 2018).

Phylogenetic analyses were performed by using neighbour joining (NJ), maximum parsimony (MP) and maximum likelihood (ML) analyses. NJ trees were generated using MEGA X (Kumar et al., 2018) with 1000 bootstrap replicates. A maximum parsimony analysis was estimated using heuristic searches, as implemented in PAUP* v.4.0b10 (Swofford, 2003). A heuristic search for the most parsimonious trees was implemented using with random addition sequence (100 repitions) and tree bisection-reconnection (TBR) branch-swapping procedure. A majority-rule consensus tree was constructed and bootstrap re-sampling (Felsenstein, 1981) based on 1000 replicates was used to assess support of relationships. According to the Akaike information criterion (AIC), jModeltest v.0.1.1 (Posada, 2008) selected the HKY+G as the best model evolution for the cyt $b$ dataset. ML analysis with 100 bootstrap replicates implemented in PhyML ver. 2.4.4 (Guindon \& Gascuel, 2003). For all phylogenetic analyses, Barbus tauricus (GenBank accession number MH010350) was used as outgroup.

\section{RESULTS}

Genetic Diversity: The complete cyt $b$ sequences were sequenced for 70 individuals belonging to three Carasobarbus. Cytochrome b (1141 bp) had 114 variable sites, 39 of which were parsimony informative. The overall nucleotide composition of the mitochondrial cyt $b$ gene is A: $30.3 \%$, G: $13.6 \%$, T: $28.6 \%$ and C: $27.5 \%$, respectively, with an A + T-rich feature (55.72\%).

In total, nine haplotypes were observed from $C$. luteus (7), C. chantrei (1) and C. kosswigi (1) (Table 2). For C. luteus, high haplotype diversity (h) and low nucleotide diversity $(\pi)$ were calculated as $\mathrm{h}=0.7040$ and $\pi=0.0026$, respectively while $C$. chantrei and $C$. kosswigi have only one haplotype each $(\mathrm{h}=0.00$ and $\pi=0.00$; Table 2).

Based on the cyt b analysis, the sequence divergence in the three Carasobarbus species (C. chantrei, C. luteus and C. kosswigi) distributed in the Euphrates, Tigris, Orontes and Kueik rivers, which are important water resources of Anatolia, were ranged from 0.026 to 0.090, whereas lower sequence divergence were between the $C$. luteus and $C$. chantrei (0.026) and maximum divergence were between the $C$. luteus and $C$. kosswigi (0.090) (Table 3).

On the other hand, intraspecific sequence divergence values range from $0.00 \%$ (C. kosswigi) to $0.21 \%$ (C. luteus) (Table 3). Also, the genetic distances between these three Carasobarbus species (C. chantrei, $C$. luteus and $C$. kosswigi) and other species in Genbank range from $0.35 \%$ to $10.92 \%$ (Table 3 ).

Species-specific nucleotide positions in the mtDNA cyt $b$ gene of Carasobarbus species are given in Figure 1 . Seven Carasobarbus species differ from each other at 166 different nucleotide positions (Figure 1).

Table 2. Origin and number of individuals from Carasobarbus species sequenced for mtDNA cytochrome b gene. Sample numbers (N), Haplotype codes (Hc), Haplotype numbers (Hn), Haplotype diversity (Hd), Nucleotide diversity (Pi).

\begin{tabular}{|c|c|c|c|c|c|}
\hline Species, River, and Locations & $\mathbf{N}$ & He & Hn & Hd & $\mathbf{P i}$ \\
\hline \multicolumn{6}{|l|}{ Carasobarbus luteus } \\
\hline Kueik River, Kilis & 15 & $\mathrm{H} 1, \mathrm{H} 2, \mathrm{H} 3$ & 3 & 0.590 & 0.0006 \\
\hline Anbar Stream, Tigris, Hani, Diyarbakır & 6 & $\mathrm{H} 1, \mathrm{H} 3$ & 2 & 0.600 & 0.0005 \\
\hline Merzimen Stream, Euphrates, Yavuzeli, Gaziantep & 2 & $\mathrm{H} 4$ & 1 & 0.000 & 0.0000 \\
\hline Karasu Stream, Euphrates, Araban, Gaziantep & 2 & H3 & 1 & 0.000 & 0.0000 \\
\hline Çamçayı Stream, Euphrates, Siverek, Şanlıurfa & 10 & H1, H3, H4 & 3 & 0.600 & 0.0006 \\
\hline Kahta Stream, Euphrates, Kocahisar, Adiyaman & 9 & H1, H3, H6, H7 & 4 & 0.833 & 0.0065 \\
\hline Çataltepe Stream, Euphrates, Kahta, Adıyaman & 3 & $\mathrm{H} 1, \mathrm{H} 5$ & 2 & 0.666 & 0.0005 \\
\hline Total & 47 & & 7 & 0.704 & 0.0020 \\
\hline Karasu Stream, Tahtaköprü Dam, Orontes, Hatay & 11 & $\mathrm{H} 8$ & 1 & 0.000 & 0.0000 \\
\hline Muratpaşa Stream, Orontes Kırıkhan, Hatay & 6 & $\mathrm{H} 8$ & 1 & 0.000 & 0.0000 \\
\hline Karasu Stream, Orontes Kırıkhan, Hatay & 6 & $\mathrm{H} 8$ & 1 & 0.000 & 0.0000 \\
\hline \multirow[t]{2}{*}{ Total } & 23 & & 1 & 0.000 & 0.0000 \\
\hline & 70 & 8 & & & \\
\hline
\end{tabular}




\section{Ingroup}

Carasobarbus kosswigi

Karkheh River, Khuzestan, Iran

Carasobarbus luteus

Khābūr River, Ghawat, Syria

Khābūr River, Ash Shaddādah, Syria

Khābūr River, Tall Tamr, Syria

Carasobarbus apoensis

Saudi Arabia museum no SMF33517

Carasobarbus chantrei

Syria, museum no SMF31016

Syria, museum no SMF31309

Carasobarbus exulatus

Saudi Arabia, museum no SMF30774

Carasobarbus canis

Israel, museum no SMF31314

Carasobarbus sublimus

Iran, museum no SMF31319

Carasobarbus harterti

Moorocco, meseum no SMF33366

Carasobarbus fritschii

Morocco, museum no SMF33481

Outgroup

Barbus tauricus

Terme Stream, Turkey

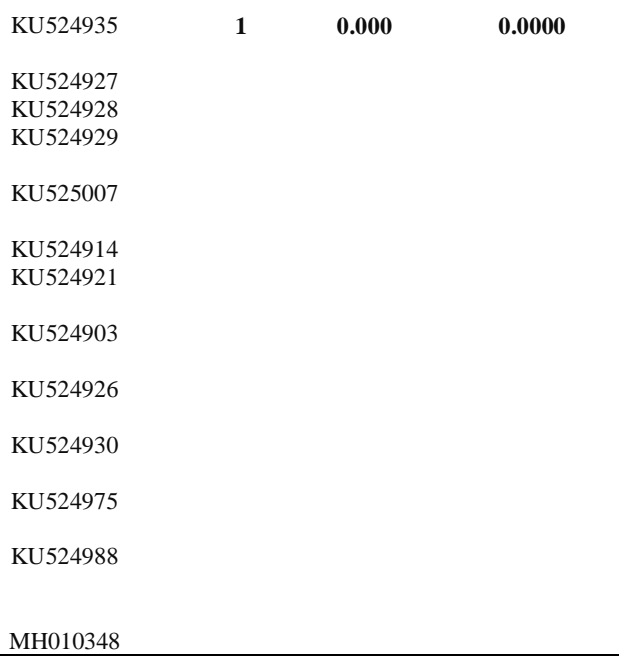

\begin{tabular}{|c|c|}
\hline & Species-specific nucleotide positions \\
\hline & \\
\hline & 1111111111111112222222333333333334444444444444555555555566666666666666666667777777777777888888888889999999999999999999900000000000000000000000000111111111 \\
\hline & 1222344567801112223466689912457891224445567900123456777899014566668801223334444556677990011123444567000114677990001122244677788999900112233444456666777889999011222333 \\
\hline & 2148018708521570395125898938350878472584898325492868124058136515890898570160128170325360612990378984147393403171792514713025924378923470358124795689478191568209268269 \\
\hline $\begin{array}{l}\text { CL- } \\
\text { H1 }\end{array}$ & ATCCACCCCTGGATACATCTTCCTGAAATCTGCTATCCACTCACAAACGTCAGGCGAAATCACGACACACATCTCGATTAACCCATCATAGCACAATACCTTGACACTTTGTGGAAATCGCCTCACACATTCTCGCACGTACCTTACCCTGTCCTATCAATGAGTC \\
\hline \begin{tabular}{|l} 
CL- \\
H2 \\
\end{tabular} & \\
\hline \begin{tabular}{|l} 
CL- \\
H3 \\
\end{tabular} & \\
\hline $\begin{array}{l}\text { CL- } \\
\text { H4 }\end{array}$ & \\
\hline $\begin{array}{l}\text { CL- } \\
\text { H5 }\end{array}$ & .A.. \\
\hline \begin{tabular}{|l} 
CL- \\
$\mathrm{H6}$
\end{tabular} & \\
\hline $\begin{array}{l}\text { CL- } \\
\text { H7 }\end{array}$ & 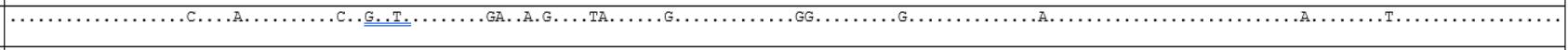 \\
\hline CA & 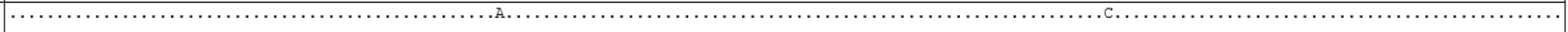 \\
\hline $\mathrm{CH}$ & 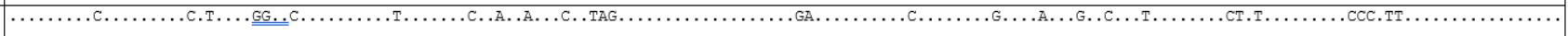 \\
\hline $\mathrm{CE}$ & 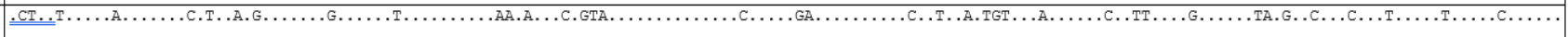 \\
\hline $\mathrm{CC}$ & 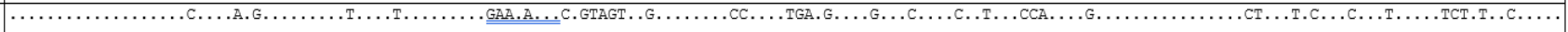 \\
\hline CK & $\ldots$. \\
\hline CS & 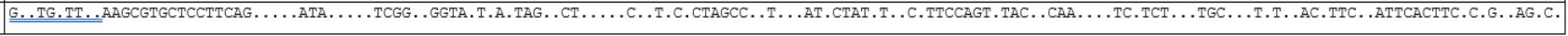 \\
\hline
\end{tabular}

CL: C. luteus, CA: C. apoensis, CH: C. chanteri, CE: C. exulatus, CC: C. canis, CK: C. kosswigi, CS: C. sublimus

Figure 1. Species-specific nucleotide positions of seven Middle Eastern species belonging to the Carasobarbus genus.

Table 3. Mean interspecific and intraspecific genetic distances of Carasobarbus.

\begin{tabular}{llccccccccc}
\hline \multicolumn{1}{c}{ Species } & $\mathbf{1}$ & $\mathbf{2}$ & $\mathbf{3}$ & $\mathbf{4}$ & $\mathbf{5}$ & $\mathbf{6}$ & $\mathbf{7}$ & $\mathbf{8}$ & $\mathbf{9}$ \\
\hline $\mathbf{1}$ & C. luteus & 0.0021 & & & & & & & & \\
$\mathbf{2}$ & C. apoensis & 0.0035 & 0.0013 & & & & & & & \\
$\mathbf{3}$ & C. chantrei & 0.0260 & 0.0263 & 0.0000 & & & & & & \\
$\mathbf{4}$ & C. exulatus & 0.0340 & 0.0324 & 0.0275 & 0.0010 & & & & & \\
$\mathbf{5}$ & C. canis & 0.0360 & 0.0341 & 0.0348 & 0.0313 & 0.0006 & & & & \\
$\mathbf{6}$ & C. harterti & 0.0666 & 0.0635 & 0.0662 & 0.0636 & 0.0606 & 0.0000 & & & \\
$\mathbf{7}$ & C. fritschii & 0.0760 & 0.0737 & 0.0764 & 0.0739 & 0.0708 & 0.0317 & 0.0066 & & \\
$\mathbf{8}$ & C. kosswigi & 0.0900 & 0.0890 & 0.0883 & 0.0864 & 0.0907 & 0.1092 & 0.1085 & 0.0000 & \\
$\mathbf{9}$ & C. sublimus & 0.0966 & 0.0957 & 0.1023 & 0.0940 & 0.1006 & 0.1063 & 0.1036 & 0.0516 & 0.0024 \\
\hline
\end{tabular}

The neighbour-joining (NJ), maximum parsimony (MP) and maximum likelihood (ML) phylogenetic methods resulted in similar trees topologies, supported by high bootstrap values (NJ:100-66, MP:100-80 and ML:100-68; Figure 2).

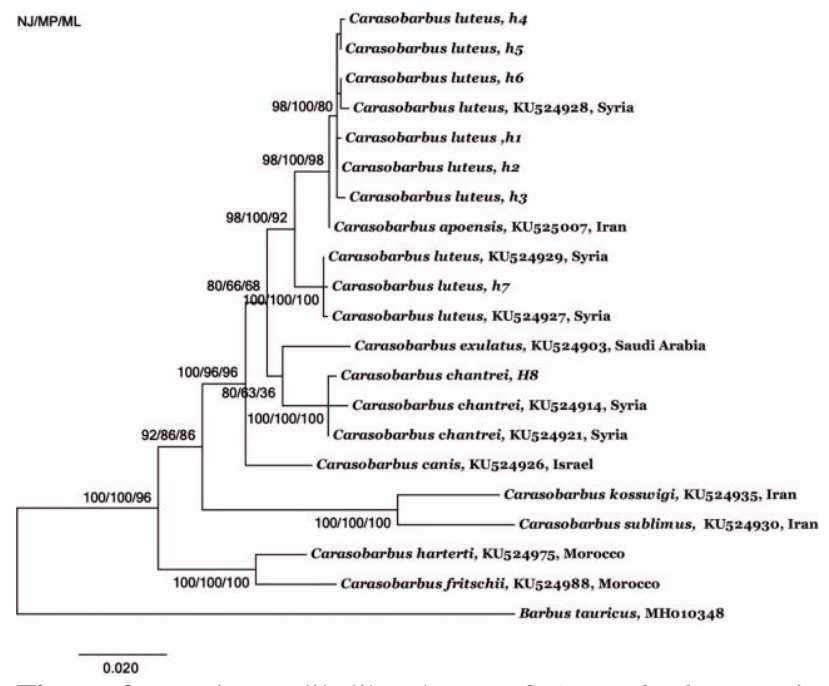

Figure 2. Maximum likelihood tree of Carasobarbus species based on the cyt $b$ gene. NJ, MP and ML methods produced identical topologies and therefore only the ML tree is shown. The numbers above the branches are bootstrap values 


\section{DISCUSSION}

Anatolia, the Asian part of Turkey, is in the region of intersection of the important biodiversity hotspots such as Caucasus, Iran-Anatolia and Mediterranean basin. One of the most distinctive biogeographical features determining the biodiversity level of Anatolia is the Anatolian diagonal, which is considered to be the biogeographical boundary between the central and eastern Anatolian fauna. During the last interglacial cycle, it is suggested the most of the populations or taxa isolated on both sides of the Anatolian diagonal diverged over time under the influence of environmental factors. (Gür, 2016). As stated in the literature (Carasobarbus luteus Heckel, 1843, Borkenhagen, 2005; Kaya et al., 2016, C. kosswigi, Borkenhagen et al., 2011; Esmaeili et al., 2006; Kaya et al., 2016 and $C$. chantrei, Borkenhagen et al., 2011; Esmaeili et al., 2006), the distribution of genus Carasobarbus Karaman, 1971 is limited to the Tigris, Euphrates, Kueik and Orontes river basin in the east of Anatolia diagonal as well as southwestern Asia and northwestern Africa. Therefore, the geographical distribution of Carasobarbus supports Anatolian diagonal model. The base composition of the cyt $b$ gene of three Carasobarbus species (lower $\mathrm{G}$ and equal $\mathrm{C}, \mathrm{A}$ and $\mathrm{T}$ ) is very similar to that previously reported for Carasobarbus (Borkenhagen et al., 2011) and other some fish species (Briolay et al., 1998; Cantatore et al., 1994; Tang et al., 2006).

Species identification depends on the detection of species-specific genetic differences in the DNA (Liu \& Cordes, 2004), and cyt $b$ sequences show significant differences even for closely related species as they have relatively high interspecies and low intraspecies variation (Aranishi et al., 2005). The presence of species-specific nucleotide positions in mitochondrial DNA cytochrome $b$ gene sequences should provide evidence for the genetic identification of three Carasobarbus species in Turkish freshwater fauna (Table 4), while $C$. apoensis and $C$. luteus species could not be distinguished. On the contrary, a significant number of specific mutations (4 SNPs, Table 4) in a haplotype $\mathrm{H} 7$ identified from the $C$. luteus population in Kahta Stream requires a morphological review of this population.

The number of haplotypes determined for $C$. luteus (7), C. chantrei (1) and C. kosswigi (1) by analysis of mDNA cyt $b$ gene is quite low (Table 2). In addition, the high haplotype diversity (Table $2 ; \mathrm{Hd}=0.590-0.833$ ) and low nucleotide diversity values (Table $2 ; \mathrm{Pi}=0.05-0.65$ ) determined for Carasobarbus species may be explained to some extent by the presence of rare small populations sensitive to genetic drift and founder effects. A similar situation was previously reported by Borkenhagen et al. (2011) for C. kosswigi and C. sublimus in the Iranian basin.
Carasobarbus kosswigi inhabits in small rivers and mountain streams and is less probably to migrate than $C$. luteus, which occupy in the lowland areas of rivers. This results in much lower gene flow among C. kosswigi populations. The low haplotypic and nucleotide diversity values (Table $2 ; \mathrm{Hd}=0.00$ ve $\mathrm{Pi}=0.00$ ) detected in the Merzimen and Karasu river samples can be attributed to the small sample size. Studies with larger sample sizes can provide useful information about population dynamics of C. kosswigi. Molecular genetic studies using mitochondrial DNA marker variation to characterize the genetic diversity of existing species are known to be particularly sensitive to sample size (Aksu \& Bektas, 2019). As a result, the small sample sizes do not have the discriminatory power needed to accurately identify samples on the basis of mtDNA genetic polymorphism (Phillips et al., 2019).

The relative genetic affinity $(2.63 \%$, Table 3$)$ between $C$. luteus and $C$. chantrei, determined based on pairwise sequence divergence, can be explained by the proximity of the sampling locations. On the other hand, the relatively high genetic distance between $C$. luteus and $C$. kosswigi (8.98\%, Table 3) with overlapping geographic distribution can be explained by their different habitat preferences, as mentioned above. In order to understand the phylogenetic relationships in the genus of Carasobarbus, analyzes were carried out using Genbank data belonging to Carasobarbus species from other regions. Inter-species genetic distances ranged from $0.44 \%$ (C. luteus and $C$. apoensis in rivers in southwest Saudi Arabia that drain into the Red Sea) to $10.91 \%$ (between C. harterti; Morocco, nortwestern Africa and C. kosswigi; Persian Gulf Basin) (Table 3). In accordance with Wright's (1943) hypothesis, our results showed that genetic distances between species are directly proportional to their geographic distances.

Phylogenetic analysis of mtDNA cytochrome $b$ haplotypes of Carasobarbus species including $C$. luteus, $C$. chantre $i$ and $C$. kosswigi, which are distributed in Anatolia, based on NJ, MP and ML methods, showed a monophyletic structure with high reliability (Figure 1). Similarly, Borkenhagen, (2017) had reported that C. apoensis, $C$. canis, C. chantrei, C. exulatus, C. fritschii, C. harterti, $C$. kosswigi, C. luteus and $C$. sublimus form a monophyletic group, based on mitochondrial cytochrome $b$ and ND4 genes. Borkenhagen, (2017) reported that the Carasobarbus genus is classified under two species groups as eastern (C. canis, C. exulatus, $C$. chanteri, C. luteus and $C$. apoensis) and western ( $C$. harherti and $C$. fritschii), $C$. kosswigi and $C$. sublimus clustered together in the phylogenetic tree. Looking at the phylogenetic tree topologies obtained from the analysis of the species belonging to the Eastern group, It will be seen that the haplotype $\mathrm{H} 7$ ( $C$. luteus) obtained from Anatolia clustered together with the Dicle-Firat haplotypes reported by 
Borkenhagen et al., (2011). What is interesting here is not the existence of two groups within the C. luteus species, but the fact that $C$. apoensis in the rivers draining into the Red Sea in Saudi Arabia is located between these groups (Figure 1). Contrary to what is expected in the obtained phylogenetic tree topologies, the merging of $C$. apoensis haplotypes into the $C$. luteus group requires a morphological review of $C$. apoensis with a large sampling group (Figure 1). In addition, the remarkable genetic distance between $C$. luteus haplotype (H7) obtained from Kahta Stream (Euphrates River) and other homologous haplotypes (H1, H3 and H6) determined in the same location requires a morphological revision of Kahta Stream samples. According to the phylogenetic tree topologies we obtained in present study (Figure 1), C. kosswigi and $C$. sublimus can be considered as a paraphyletic group since they contain only a part of Carasobarbus species originating from a common ancestor. Moreover, this suggestion had suggested by Borkenhagen et al., (2011), which previously made the molecular systematics of Carasobarbus, based on the mitochondrial genome.

Wang et al., (2013) suggested that the Torini group, which includes the Carasobarbus lineage, arised in the east about 9.94 million years ago (mya), and the Carasobarbus lineage diverged from others by about 7.7 mya. The Anatolian diagonal extending in the north-east south-west direction in Anatolia, which is the source region of European colonization, is an obstacle to the colonization of Europe by organisms from the Near East (Ansell et al., 2011). As a result of the collision of the African and European plates, the rise of the Pliocene Anatolian plateau (orogenic activity) and global climatic changes probably (Durand et al., 2002; Fairbridge et al., 1997) caused the disconnection of the wide river connections in Anatolia and thus prevented the presence of Carasobarbus in the fauna in the west of the Anatolian diagonal. The fact that the genus Carasobarbus has no distribution in the east of the Anatolian diagonal can be explained by the paleogeographic history of the region.

\section{ACKNOWLEDGMENTS}

This work was funded by the scientific research funds of Recep Tayyip Erdogan University (RTEÜ BAP, Project No: 2015.53008.103.01.01).

\section{REFERENCES}

Abdoli, A. (2000). The Inland Water Fishes of Iran. Iranian Museum of Nature and Wildlife, Tehran. 378 pp. In Farsi.

Aksu, I. \& Bektas, Y. (2019). Multilocus Phylogeny of the Family Sparidae in Turkish Coastal Waters Based on Mitochondrial DNA Sequences. Anatolian Env. and Anim. Sciences, 4(3), 491-499. DOI: 10.35229/jaes.627821.

Anderson, S., Bankler, A.T. \& Barrel, B.G. (1981). Sequence and organization of the human mitochondrial genome. Nature, 290, 457-465.

Ansell, S.W., Stenlien, H.K., Grundmann, M., Russell, S.J., Koch, M.A., Schneider, H. \& Vogel, J.C. (2011). The importance of Anatolian mountains as the cradle of global diversity in Arabis alpina, a key arctic - alpine species. Annals of Botany, 108, 241252.

Aranishi, F., Okimoto, T. \& Izumi, S. (2005). Identification of gadoid species (pisces, Gadidae) by PCR-RFLP analysis. Journal of Applied Genetics, 46, 69-73.

Borkenhagen, K. \& Krupp, F. (2013). Taxonomic revision of the genus Carasobarbus Karaman, 1971 (Actinopterygii, Cyprinidae). ZooKeys, 339, 1-53.

Borkenhagen, K. (2005). Systematik und Zoogeographie der "großschuppigen Barben" des Vorderen Orients. ChristianAlbrechts-Universität, Kiel

Borkenhagen, K. (2017). Molecular phylogeny of the tribe Torini Karaman, 1971 (Actinopterygii: Cypriniformes) from the Middle East and North Africa. Zootaxa, 4236, 291-301.

Borkenhagen, K., Esmaeili, HR., Mohsenzadeh, S. \& Shahryari, F.G.A. (2011). The molecular systematics of the Carasobarbus species from Iran and adjacent areas, with comments on Carasobarbus albus (Heckel, 1843). Environmental Biology of Fishes, 91, 327-335. DOI: $10.1007 / \mathrm{s} 10641-011-9787-1$.

Briolay, J., Galtier, N., Brito, R.M. \& Bouvet, Y. (1998). Molecular phylogeny of Cyprinidae inferred from cytochrome b DNA sequences. Molecular Phylogenetics and Evolution, 9, 100-108. DOI: 10.1006/mpev.1997.0441.

Cantatore, P., Roberti, M., Pesole, G., Ludovico, A., Milella, F., Gadaleta, M.N. \& Saccone, C. (1994). Evolutionary analysis of cytochrome $b$ sequences in some perciformes evidence for a slower rate of evolution than in mammals. Journal of Molecular Evolution, 39, 589-597.

Durand, J.D., Tsigenopoulos, C.S., Ünlü, E. \& Berrebi, P. (2002). Phylogeny and biogeography of the family Cyprinidae in the Middle East inferred from cytochrome b DNA - Evolutionary significance of this region. Molecular Phylogenetics and Evolution, 22, 91-100. DOI: 10.1006/mpev.2001.1040.

Esmaeili, H.R., Teimory, A., Hosseini, F. \& Gholami, Z. (2006). Range extension report for Barbus sublimus Coad and Najafpoor, 1997 (Actinopterygii Cyprinidae) along with its sympatric species in southwest Iran. Iranian Journal of Animal Biosystematics, 2, 19-24.

Fairbridge, R., Erol, O., Karaca, M. \& Yilmaz, Y. (1997). Background to Mid-Holocene climatic change in Anatolia and adjacent regions. In Dalfes, H.N., Kukla, G., Weiss, H. (Eds.), Third 
Millennium BC Climate Change and Old World. Collapse NATO ASI series 1 149. Springer, Berlin, 595-609.

Felsenstein, J. (1981). Evolutionary trees from DNA sequences a maximum likelihood approach. Journal of Molecular Evolution, 7, 368-376.

Froese, R. \& Pauly, D. (2015). Fishbase. World Wide Web Electronic Publication. Avaliable http//www.fishbase.org (May 30, 2019).

Gökçek, C.K., Mazlum, Y. \& Akyurt, I. (2008). Effect of feeding frequency on the growth and survival of himri barbel Barbus luteus (Heckel, 1843), fry under laboratory conditions. Pakistan Journal of Nutrition, 7, 66-69.

Guindon, S. \& Gascuel, O. (2003). A simple, fast, and accurate algorithm to estimate large phylogenies by maximum likelihood. Systematic Biology, 52(5), 696-704.

Gür, H. (2016). The Anatolian diagonal revisited testing the ecological basis of a biogeographic boundary. Zoology in the Middle East, 623, 189-199.

Hall, T.A. (1999). BioEdit: A user-friendly biological sequence alignment editor and analysis program for Windows 95/98/NT. Nucleic Acids Symposium Series, 41, 95-98.

Karaman, M.S. (1971). Süßwasserfische der Türkei. 8. Teil: Revision der Barben Europas, Vorderasiens und Nordafrikas. Mitteilungen aus dem Hamburgischen Zoologischen Museum und Institut, 67, 175-254.

Kaya, C., Turan, D. \& Ünlü, E. (2016). The latest status and distribution of fishes in upper tigris river and two new records for Turkish freshwaters. Turkish Journal of Fisheries and Aquatic Sciences, 16, 545562.

Kimura, M. (1980). A simple method for estimating evolutionary rates of base substitutions through comparative studies of nucleotide sequences. Journal of Molecular Evolution, 16, 111-120.

Kumar, S., Stecher, G., Li, M., Knyaz, C. \& Tamura, K. (2018). MEGA X: Molecular evolutionary genetics analysis across computing platforms. Molecular Biology, 35, 1547-1549.

Kuru, M. (1979). The freshwater fish of South-Eastern Turkey-2 (euphrates-tigris system). Hacettepe Bulletin of Natural Sciences and Engineering, 7, 105-114.
Librado, P. \& Rozas, J. (2009). DnaSP v5: A software for comprehensive analysis of DNA polymorphism data. Bioinformatics, 25, 1451-1452.

Liu, Z.J. \& Cordes, J.F. (2004). DNA marker technologies and their applications in aquaculture genetics. Aquaculture, 238, 1-37.

Parmaksız, A. \& Eskici, H.K. (2018). Genetic variation of yellow barbell (Carasobarbus luteus Heckel, 1843) from four populations using mitochondrial DNA COI gene sequences. Applied Ecology and Environmental Research, 16, 1673-1682.

Phillips, J.D., Gillis, D.J. \& Hanner, R.H. (2019). Incomplete estimates of genetic diversity within species Implications for DNA barcoding. Ecology and Evolution, 9, 2996-3010.

Posada, D. (2008). jModelTest: phylogenetic model averaging. Molecular Biology and Evolution, 25(7), 1253-1256.

Sauvage, H.E. (1882). Catalogue des poissons recueillis par M. E. Chantre pendant son voyage en Syrie, Haute-Mésopotamie, Kurdistan et Caucase. Bulletin de la Société philomathique de Paris, 6, 163-168.

Swofford, D.L. (2003). PAUP. Phylogenetic Analysis Using Parsimony. Version 4. Sinauer Associates, Sunderland, Massachusetts.

Tang, Q., Liu H., Mayden, R. \& Xiong, B. (2006). Comparison of evolutionary rates in the mitochondrial DNA cytochrome $b$ gene and control region and their implications for phylogeny of the Cobitoidea (Teleostei Cypriniformes). Molecular Phylogenetics and Evolution, 39, 347-357.

Ünlü, E. (1991). Investigation on the biological characteristics of Capoeta trutta (Heckel, 1843) living in Tigris River. Turkish Journal Of Zoology, 15, 12-38.

Wang, J., Wu, X.Y., Chen, Z., Yue, Z., Ma, W., Chen, S.Y., Xiao, H., Murphy, R.W., Zhang, Y.P., Zan, R.G. \& Luo, J. (2013). Molecular phylogeny of European and African Barbus and their West Asian relatives in the Cyprininae (Teleostei Cypriniformes) and orogenesis of the QinghaiTibetan Plateau. Chinese Science Bulletin, 58, 3738-3746.

Wright, S. (1943). Isolation by distance. Genetics, 28, 114-138. 